\section{THE ENDOWMENT OF RESEARCH IN FRANCE.}

$A^{T}$ the meeting of the Paris Academy of Sciences on April 27 , the Secretary read the following extract from the will of the late M. Cahours :-

"I have frequently had the opportunity of observing, in the course of my scientific career, that many young men, distin. guished and endowed with real talent for science, saw themselves obliged to abandon it because at the beginning they found no efficacious help which provided them with the first necessities of life and allowed them to devote themselves exclucively to scientific studies.

"With the object of encouraging such young workers, who for" the want of sufficient resources find themselves powerless to finish works in course of execution, and in remembrance of my beloved children, who also would walk in a scientific path at the moment when death takes me from them, I bequeath to the Academy of Sciences, which has done me the honour to admit me into its fraternity, a sum of one hundred thousand francs.

"I desire that the interest of this sum may be distributed every year by way of encouragement to any young men who have made themselves known by some interesting works, and more particularly by chemical researches.

"In order to assure this preference, independently of the express recommendation that I make here to my successors, I wish that, during at least twenty-five years after the commencement of the interest payable to the Academy, three members at least of the Chemistry Section may take part each year in a Commission of five members charged by the Academy to distribute the prizes. I express further the formal desire that this choice should fall, as far as possible, on young men without fortune not having salaried offices, and who, from the want of a sufficient situation, would find themselves without the possibility of following up their researches.

"These pecuniary encouragements ought to be given during several years to the same young men, if the Commission thinks that their productions have a value which permits such a favour.

"Nevertheless, in order that the largest number of young workers may participate in the legacy I institute, I desire that the encouragements may cease at the time when the young savants who have enjoyed them obtain sufficiently remunerative positions."

M. Janssen then made the following remarks :-

"The legacy which has been made to the Academy, by our very eminent and very regretted confrive, appears to me to have considerable import not only by its importance, but especially by the way that it opens, and the example that it affords, to all those who hereafter may desire to encourage the sciences by their jiberality.

"M. Cahours, whose sure judgment and long experience enabled him to know the most urgent necessities of science, had, like most of us, become convinced of the necessity of introducing a new form in the institution of scientific recompenses.

"Our prizes will always continue to meet a great and noble necessity ; their value, the difficulty of obtaining them, and the éclat they take from the illustriousness of the body which awards them, will make them always the highest and most envied of recompenses.

"But the value, also, of the works it is necessary to produce in order to lay claim to them prohibits the research to beginners. It is a field that is only accessible to matured talents.

"But, besides those savants who have already an assured career, there are many young men endowed with precious aptitules, and directed by their inclination to pure science, but turned very often from this envied career by the difficulties of existence, and taking with regret a direction giving more immediate results. And yet, how many among them possess talents which, if , well cultiva'ed, might do honour and good to science !

"We must say, however, that it is in leaving their studies that those who wish to devote themselves to pure science experience the most difficult trials, and these difficulties are increased every day by the very rapid advance of the exigencies of life.

"We must find a prompt remerly for this state of things if we do not wish to see the end of the recruitment of science. NO. 1123 , VOL. 44$]$
"This truth, however, is beginning to be generally felt. The Government has already created institutions, scholarships, and encouragements, which partly meet the necessity. Some generous. donors are also working in this manner. I will mention especially the roble foundation of Mdlle. Dosne, in accordance with whose intentions a hall is at this moment being built, where young men, having shown distinguished aptitudes for high administration, the bar, or history, will receive for three years all the means of carrying on high and peaceful studies.

"Let us say, then, plainly, and in speaking thus we only feebly echo the expressions of the most illustrious members of the Academy, that it is by following the way so nobly opened by Cahours that the interests and prospects of science will be most efficaciously served."

\section{NOTES.}

A SPECial meeting of the Physical Society of London will be held at Cambridge on Saturday, May 9. The members will leave Liverpool Street at I I a.m., and on arrival at Cambridge will become the guests of the Cambridge members. The meeting will be held in the Cavendish Laboratory at 2.30. The following communications will be read: some experiments on the electric discharge in vacuum-tubes, by Prof J. J. Thomson, F.R.S. ; some experiments on ionic velocities, by Mr. W. C. D. Whethain; on the resistance of some mercury standards, by Mr. R. T. Glazebrook, F.R.S. ; on an apparatus for measuring the compressibility of liquids, by Mr. S. Skinner; some measurements with the pneumatic bridge, by Mr. W. N. Shaw. After the meeting members will have an opportunity of seeing the Cavendish Laboratory and other University Laboratories.

THE annual meeting of the Iron and Steel Institute began yesterday, and will continue to-day and to-morrow. It is being held as usual at the Institution of Civil Engineers in Great George Street.

A valuable bequest has been made to the Department of Science and Art by the late Miss Marshall, of 92 Warwick Gardens, Kensington. In addition to a large number of scientific books and instruments which are left for the use of students, a sum of $f_{\mathrm{I}} \mathrm{O} 000$ is bequeathed for the founding of scholarships, or for application in any other way that may be considered best for the advancement of biolugical science.

THE Queen has approved the appointment of Lord Derby to be Chancellor of the University of London, in the room of the late Lord Granville.

THE death of Prof. Joseph Leidy, in his sixty-eighth year, is announced. He was Professor of Anatomy in the University of Pennsylvania and of Natural History in Swarthmore College; President of the Academy of Natural Sciences of Philadelphia; and I Sirector of the Department of Biology in the University. In a future number we shall give some account of his services to science.

A REUTER's telegram from New York, dated May I, announces the death, at Berkeley, California, of Prof. John Le Conte, brother of Mr. Joseph Le Conte, formerly professor of geology and natural history in the University of California.

WE regret to have to announce the death of Captain Cecilio Pujazon, the Director of the Marine Observatory of San Fernando, near Cadiz. He died on April 15, in his fifty-seventh year. Captain Pujazon was well known to the members of the Eclipse Expedition of 1870 , who formed the Cadiz party. $\mathrm{He}$ came to London to the Conference on Marine Meteorology in 1874 .

IN answer to a question put by Mr. H. Fowler in the House of Commons on Monday, Sir W. Hart Dyke said that from the returns already received, in answer to a circular issued by the 